\title{
The Strategies for Minimizing the Linear Dislocation between Arabic - Javanese Translation of Islamic Moral Ethic Books
}

\author{
Muhammad Yunus Anis \\ Department of Arabic Literature \\ Universitas Sebelas Maret (UNS) \\ Surakarta, Indonesia \\ yunus_678@staff.uns.ac.id
}

\begin{abstract}
Theme and Rheme in Arabic Javanese translation, especially in Islamic Moral Ethic Books. The construction of Theme and Rheme had been related dominantly with textual equivalence between Arabic language (L1) and Javanese language (L2). There are two basic problems in this research, first, how was the structural model of textual equivalence based on the information construction (Theme and Rheme). Theme had been related with the starting point of the information and also the given information, and Rheme had been represented as the new information. The first problem will investigate the variant models of Theme and Rheme between Arabic and Javanese language. The second problem will elaborate the strategies for minimizing the linear dislocation between Arabic (L1) and Javanese language (L2). The method in this research had been divided into three basic steps, such as: (1) collecting the data using the observation method through the units of language between $L 1$ and $L 2$, such as word, phrase, clause, and sentence. (2) Analyzing the data using the model of Miles and Huberman, reducing the data, display data, and conclusion. (3) Reporting the data about two basic findings: the variant models of Theme and Rheme and the strategies for reducing the linear dislocation between Arabic and Javanese translation. There are four strategies for resolving the tension between syntactic and communicative functions in ArabicJavanese translation, such as: (1) voice change, (2) change of verb, (3) nominalization, and (4) extraposition.
\end{abstract}

Keywords - arabic - javanese translation; theme and rheme; textual equivalence; islamic moral ethic books

\section{INTRODUCTION}

This research will investigate the textual equivalence between Arabic and Javanese translation. Many scholars had been defined the term of "equivalence" in translation studies. Catford (1978, p. 21) had been concluded that the term "equivalence" was the key concept in translation studies, because the central problem of translation practice is that of finding target language (TL) translation equivalents. Catford also emphasized that a central task of translation theory is that of defining the nature and conditions of translation equivalence. The word "equivalent" as something of the same value/same strength in Arabic language can be defined by the words /musāwin li/ (مساو لـ) or /mu'ādil/ (معادل) (Collin, 1990, p. 178). To gain the information structure between Arabic and Javanese language, this research will try to elaborate the construction of Theme and Rheme between Arabic and Javanese language. The main data in this research was the Islamic moral ethic book, such as "Tarjamah TanbīhulGhāfilīn" (the translation book of "Forewarning for the Mindless"). This book had been translated into Javanese language by Kyai Mishbāch Ibnu Zain al-Mushthafā. This textual book had been selected as the main data because it has two models of translation method, word for word method and free translation method. Both of two methods had been found in the target language (Javanese language - L2). This research tried to unlock the diversity in language between Arabic (L1) and Javanese language (L2) based on grammatical aspect and information packaging (Theme and Rheme).

The previous research about the translation of Theme and Rheme in Arabic language had been elaborated by Almanna (2016, p. 138). This research had been focused in the annotating aspects of Thematic Progression between Arabic (L1) and English (L2). On the other hand, Anis (2016, p. 255) had been elaborated the translation of an object inside the Arabic Theme and Rheme construction. This research had described the variant structure of objects which had been occurred in the Arabic Theme and Rheme construction using the translation perspective. Anis (2015) emphasizes that in Arabic texts, the Theme and Rheme can be developed in certain patterns (thematic progression patterns). Anis (2018) outlines and compares the constructions of Theme and Rheme in the Arabic and Javanese languages. On the other hand, Sukesti (2011) investigates the construction of Theme and Rheme in the Javanese "Ngoko Banyumas" dialect. Suparno (1993) also investigates Theme and Rheme constructions, focusing on the local dialect of Malang, East Java, Indonesia. These recent research studies are primarily structurally focused.

\section{METHOD}

This research uses a qualitative method. The data is analyzed using a descriptive method (describing the structure of language). The method in this research is divided into three main parts: (1) data collection, (2) data analysis, and (3) data reporting. The data collection uses a method of observation to obtain information about the two mains problems: (1) the 
variant models of Theme and Rheme between Arabic and Javanese language and (2) the strategies for minimizing the linear dislocation between Arabic (L1) and Javanese language (L2). The first problem had been related with the variant models of information construction (Theme and Rheme). The data had been selected from the units of language such as: nominal sentence (jumlah ismiyyah) and verbal sentence (jumlah fi'liyyah). Then, both of sentence were identified the position of Theme and Rheme in source language (L1: Arabic) and target language (L2: Javanese). The data had shown that the Theme in Arabic language had been constructed from the nominal group and verbal group. In the second step, it had been found the special markers for Theme and Rheme in Javanese language. In the second problem, the data had been reduced by the problems which related to linear dislocation between Arabic and Javanese translation. Miles (1994, p. 10) had been concluded that qualitative analysis was consisting of three concurrent flows of activity: data reduction, data display, and conclusion drawing/ verification. Data reduction refers to the process of selecting, focusing, simplifying, abstracting, and transforming the data that appear in written-up field notes or transcriptions. The data reduction in this research had been focused in the variant models of Theme and Rheme and the strategies for minimizing the linear dislocation between Arabic and Javanese translation. Data reduction is not something separate from analysis. It is part of analysis. Data display is an organized, compressed assembly of information that permits conclusion drawing and action. Data display in this research had been viewed in the table and figure to elaborate the nominal group and verbal group as Theme in Arabic language and then to conclude the variant markers of Theme and Rheme in target language (L2). The third stream of analysis activity is conclusion drawing and verification. From the start of data collection, the qualitative analyst is beginning to decide what things mean - is noting regularities, patterns, explanations, possible configurations, causal flows, and propositions.

\section{RESULT AND DISCUSSION}

By outlining the problems in this research, it can be seen that there are two mains findings and areas of discussion: (1) the variant models of Theme and Rheme between Arabic and Javanese language, (2) the strategies for minimizing the linear dislocation between Arabic (L1) and Javanese language (L2). The analysis in this section uses a descriptive qualitative research. The main data in this research is taken from selected units of language in the book "Tarjamah Tanbīhul-Ghāfilīn", which had related to the Theme and Rheme construction, both in the form of nominal sentences and verbal sentences in the Arabic language. The first problem focuses on linguistic aspects and the second problem focuses on theories of translation studies.

\section{A. The Variant Models of Theme and Rheme between Arabic and Javanese Language}

In this section, the Arabic - Javanese translation will be elaborated based on thematic structure (clause as a message). In all languages, the clause has the character of a message: it has some form of organization giving it the status of a communicative event. Halliday (1994, p. 37) emphasized that every language had the construction of Theme and Rheme. Some languages had the marker of theme, such as in Japanese language. The theme had been followed by the reminder so that the two parts together constitute a message. The Theme (written with an initial capital) is the element which serves as the point of departure of the message; it is that with which the clause is concerned. The remainder of the message, the part in which the Theme is developed, is called the Rheme (written with an initial capital). Within this configuration, the Theme is the starting-point for the message; it is the ground from which the clause takes off. Therefore, part of the meaning of any clause lies in whichever element is chosen as its Theme. There is a difference in meaning between 'al-Mukhlish is the one who strives for sincerity', where al-Mukhlish is the Theme ('I'll tell you about al-Mukhlish'), and 'the one who strives for sincerity is al-Mukhlish', where the one who strives for sincerity is the Theme ('I'll tell you about the one who strives for sincerity'). The difference may be characterized as 'thematic'; the two clauses differ in their choice of Theme. By glossing them in this way, as 'I'll tell you about ...', we can sense that they are two different messages. The Rheme of a sentence is the core (focus) of an utterance from the point of view of functional sentence perspective (Vachek, 2003, p. 141). The first variant of Theme in Arabic language had been constructed from a NOMINAL GROUP such as in the TABLE 1 below.

TABLE I. EXAMPLE OF NOMINAL GROUP AS THEME IN ARABIC AND JAVANESE TRANSLATION

\begin{tabular}{|l|l|}
\hline \multicolumn{2}{|c|}{ Nominal Group as Theme } \\
\hline Wa washiyyatiy lahu (L1) & $\begin{array}{l}\text { an andzura fihi bit-tadzakkuri wat-tafakkuri } \\
\text { linafsihi awwalan (page 7) }\end{array}$ \\
\hline $\begin{array}{l}\text { Utawi washiyat ingsun - } \\
\text { marang wong (L2) }\end{array}$ & $\begin{array}{l}\text { Iku yentho - ningali wong - ing dalem kitabe - } \\
\text { kelawan angen-angen - lan mikir-mikir- } \\
\text { marang uwong-dewene wong - ing dalem } \\
\text { kawitane }\end{array}$ \\
\hline Theme & Rheme \\
\hline
\end{tabular}

In table 1, the theme had been constructed from the nominal group /wa washiyyatiy lahu/, "and my testament for him". The theme had been followed by the rheme, /an andzura fihi bit-tadzakkuri wat-tafakkuri../, "please look at the book using the consideration and reflection". The nominal group as theme had been found in the Arabic nominal clause (jumlah ismiyyah). This clause was the testament from the author of the book Tanbihul-Ghäfilin for the reader to read the book using the sense of reflection because this book related with the Islamic moral ethic. Before you judge the others, you should judge yourself. In Javanese translation the marker of the Theme is the word "utawi" and then the marker of the Rheme is the word "iku". The word "utawi" had started the given information, and the word "iku" considered as the beginning of the information.

In the book of Islamic moral ethic book, the Theme is not necessarily a nominal group, like in the Fig. 1. It may also VERBAL GROUP, such as in the Fig. 2 below. Some of verbs had been represented as the starting point or the point of departure of the message, such as: /qāla/, 'said', /ruwiya 'an/, 'had been told', /chaddatsanā/ 'had been told for us' or 'had 
been narrated to us', /rawā/ 'told', /wa qīla li../ 'had been narrated to..'. This is the main character of Islamic moral ethic book, the starting point of the message using the statements or quotations from the Prophet Muhammad SAW or his followers (shachābah Rasulullah: the companions of the Prophet). The Theme represented the owner of the quotation, and then followed by the Rheme as the substance of the quotation. The Theme which had been constructed from the verbal group can be looked at from the table 2 below.

TABLE II. EXAMPLE OF VERBAL GROUP AS THEME IN ARABIC AND JAVANESE TRANSLATION

\begin{tabular}{|c|c|}
\hline \multicolumn{2}{|c|}{ Verbal Group as Theme } \\
\hline $\begin{array}{l}\text { (wa qūla liba'dhil- } \\
\text { chukamà'i) }\end{array}$ & $\begin{array}{l}\text { Manil-mukhlish qāla al-mukhlishu alladzi } \\
\text { yaktumu chasanātihi kamā yaktumu sayyiātihi } \\
\text { (page 49) }\end{array}$ \\
\hline $\begin{array}{l}\text { Lan den utaraake } \\
\text { marang sakwenehe wong } \\
\text { wong ahli hikmah }\end{array}$ & $\begin{array}{l}\text { Iku sinten utawi tiyang ingkang ikhlas? Dawuh } \\
\text { wong ahli hikmah - utawi mukhlish iku wong } \\
\text { kang ngumpetake ing piro piro kebagusane } \\
\text { koyo yentho ngumpetake piro-piro olone }\end{array}$ \\
\hline Theme & Rheme \\
\hline
\end{tabular}

In the Fig. 2, the Theme had been constructed from the word /qīla/ 'had been said (by the wise man)' (Eng.), 'lan den utaraake' (Javanese) as the passive voice. The wise man/ Islamic philosopher had been described about "al-mukhlish" (the sincere). The Rheme is the substance of the wise man words about al-mukhlish who is hiding his kindness as when he was hiding his badness. The verbal group as Theme had been found in the verbal clause (jumlah fi'liyyah). Thus it can be concluded that the Theme in Islamic moral ethic book is announced by the nominal group and verbal group. The translation marker of Theme in target language nominal group is the word "utawi". The translation marker of Rheme in target language (Javanese) nominal group is the word "iku". In the verbal group, the Theme represented as the owner of the quotation and the Rheme elaborated the substance of quotation. On the other hand, there was a theme which had been consisted from the imperative verb such as $/ u d^{\prime} u$ ila sabilli rabbika bil-chikmati wal-mau'idzatil chasanatil (page:5), it had been translated into "ajak-ajako siro Muhammad - marang dalane - pengeran niro - kelawan hikmah - lan pitutur kang bagus. The word /ud'u/ (to call - to invite - to ask to come) had been translated into Javanese language "ajak-ajako siro Muhammad". This word was imperative verb in Arabic and it had been translated into Javanese language as imperative verb. The word / $\mathrm{ud}^{\mathrm{t}} \mathrm{u} / \mathrm{had}$ been identified as Theme in Verbal group as the imperative verb. The character of Islamic moral ethic book when elaborating the sunnah or hadith (prophetic tradition/sayingof the prophet) had been used the special phrase (verbal group) as Theme such as: /wa bimā waradat bihi as-sunnatu .../. The verb /warada/ in Arabic language (to be mentioned or to be stated) had been translated into Javanese language as "tumeko". This verbal group (bimā + the verb warada + bi) had been translated into Javanese language "lan sebab barang - kang tumeko - kelawan ma - opo hadis" (p. 5). In the free translation model, this verbal group had been translated into Javanese language "lan uga sebab hadis kang wus teka marang kita ya iku ya iku ... “.

\section{B. The Strategies for Minimizing the Linear Dislocation between Arabic and Javanese Language}

There are four main strategies had been implemented in the text of Tarjamah Tanbīhul-Ghäfilinn (Arabic - Javanese), such as: (1) voice change, (2) change of verb, (3) nominalization, and (4) extraposition.

(Strategy no. 1: voice change). Baker (2011, p. 176) had concluded that this strategy involves changing the syntactic form of the verb to achieve a different sequence of elements. A good example of this is voice change in languages with a category of voice. The reverse, the substitution of passive for active, is of course possible. To gain the implementation of strategy 1 to minimize the linear dislocation between Arabic and Javanese language, we can compare between active and passive verbs between two languages (L1) and (L2). The active voice in Arabic verb in Islamic moral ethic book dominantly related with the quotation, such as: Iwa qāla 'Abdullah ibnu Chanifl 'and Abdullah ibnu Chanif had been said .... ', this clause had been translated into L2/ Javanese language "lan dawuh sopo Abdullah ibnu Chanif .." (p. 48). On the other hand, the verb /qāla/ occurred as passive voice and it has been changed into /qīla/, such as in this clause: /wa qūla lidzin-Nūn Al-Mishriy.../ 'it has been said to Dzun Nun Al-Mishriy...", this clause had been translated into L2 "lan den utaraake marang Dzin-Nun Al-Mishriy..” (p. 49). If we look at this verb, there was a shifting meaning between active and passive, the word /qāla/ active had been translated into L2 "dawuh", and the word /qīla/ passive had been translated into L2 by the word "den aturake". This is the way from the translator to minimize the liniear dislocation between L1 and L2. The word "dawuh" in Javanese language has the tendency to the meaning of "speaking" and the word "aturake" has the tendency of "convey". The active voice also had the clear subject, but the passive voice had unclear subject, thus the affix "den" and "e" in the word "den aturake" were becoming the marker of passive voice in Javanese language.

(Strategy no. 2: change of verb). Baker (2011, p. 177) had been concluded that the strategy no. 2: change of verb involves changing the verb altogether and replacing it with one that has a similar meaning but can be used in a different perspective in English include give/get and like/please. Those often allow reordering the sequence of elements in a clause without a significant change of meaning (cf. I like it and it pleases me). The strategy 2 had been implemented in the Islamic moral ethic book by the description technique of translation between Arabic and Javanese language. For example, the word khawassh in Arabic language had been translated into "wong-wong khususe Allah" or "the special persons belong to Allah". The word khawāsh is the Sufism term; it will be difficult to translate the special term. The similar meaning in the strategy 2 can be looked at the word /al'äjilah/ and the word /ad-dunya/. The first had been translated into L2 by "ing "amal dunyo" in the clause /man kāna yurīdu al-'ājilata 'ajjalanā lahu fì hā, ya'ni man arāda bi'amalihi ad-dunya/. The word /al-'äjilah/ and the word /addunya/ both of them had a similar meaning (world). In the other word, the term as-sunnah had been translated into the term /chadīs/. It can be found from the data below / wa bimā waradat bihi as-sunnah/, it had been translated into Javanese 
language /lan sebab barang- kang tumeko-kelawan ma- opo chadis/ (p. 5).

(Strategy no. 3: nominalization). Baker (2011, p. 178) explained that the nominalization involves replacing a verbal form with a nominal one (e.g. describe - description). In the Arabic - Javanese, there was a shifting translation from the category of noun (Source Language: L1) into verb (Target Language: L2). It can be found from the data below /bitadzkīi lighairih/. This phrase had been translated into Javanese language /kelawan ngelengake- marang liyane nafsihil (page 7), the word tadzkīr (reminding: English) is a noun in Arabic language, it had been translated into Javanese language as a verb "ngelengake" (to remind: English). There was a nominalization between Arabic and Javanese language.

(Strategy no. 4: extraposition). Baker (2011, pp. 179180) had been elaborated that extraposition involves changing the position of the entire clause in the sentence, for instance by embedding a simple clause in a complex sentence. The embedding a simple clause in a complex sentence in ArabicJavanese translation had been occurred to make the statement more clear in the target language, especially to refer some unit of language into the previous statement in the text, for example in the data below /wa ruwiya 'an Rasulillähi shallaAllahu 'alaihi wa sallam annahu qāla tafakkuru sā'atin khairun min ibādati sanatin/. This data had been translated into Javanese language (free translation) as follow /diceritaake sangking Rasulullah Shalallahu 'Alaihi wa sallam, panjenengane dhawuh: angen-angen ing mongso sak jam (kang bisa nimbulake rasa ta'dzim) marang Allah iku luwih bagus katimbang ibadah setahun/. In this case to explain the word /sā'atun/ "an hour", the translator added the embedded clause /kang bias nimbulake rasa ta'dzim marang Allah/ "an hour which can make the person to increase his respect to the God". The embedded clause has not appear in the source language, but it has been found in the target language to make the product of translation more clear. This is the way, how the translator minimizes the linier dislocation between Arabic and Javanese language.

\section{CONCLUSION}

There are two main results here: (1) the variant models of Theme and Rheme between Arabic and Javanese language and (2) the strategies for minimizing the linear dislocation between Arabic (L1) and Javanese language (L2). The results of the data analysis show that the information packaging in Islamic moral ethic book of Tanbīhul-Ghāfilīn had been found both in nominal clause (jumlah ismiyyah) and verbal clause (jumlah fi'liyyah). The Theme in Islamic moral ethic book is announced by the nominal group and verbal group. The translation marker of Theme in target language nominal group is the word "utawi". The translation marker of Rheme in target language (Javanese) nominal group is the word "iku". In the verbal group the Theme represented as the owner of the quotation and the Rheme elaborated the substance of quotation. There are four strategies to minimize the linear dislocation between Arabic and Javanese translation in the Islamic Moral Ethic Book, they are: (1) voice change, (2) change of verb, (3) nominalization, and (4) extraposition.

\section{Acknowledgment}

This research was supported by LPPM UNS. The Institution of Research and Servitude toward the Society, under the Fundamental research grant (Hibah Penelitian Fundamental PNBP UNS 2018).

\section{References}

Almanna, A. (2016). The routledge course in translation annotation: Arabic-English-Arabic. London: Routledge.

Anis, M. Y. (2015). Pengembangan tema dalam buku AlQira'ah Ar-Rasyidah sebagai pondasi awal dalam latihan menulis kreatif bahasa Arab". Jurnal Arabivat. 2(2). 1-10.

Anis. M. Y. (2016). The translation of an obiect in Arabic theme and rheme constructions. Proceedings ICOLTS 2016: International Conference on Linouistics \& Translation Studies: 255-266. Solo. 15-16 November 2016: English Department. Facultv of Cultural Sciences and Linguistics Master Program: Post Graduate School Universitas Sebelas Maret.

Anis. M. Y. \& Arummi. A. \& Farhah. A. (2018). Between arabic and iavanese translation: case studv in textual equivalence of islamic moral ethic book. advances in social science. Education and Humanities Research (ASSEHR). 154. nn. 161-165. Published bv Atlantis Press. this article had been presented at the International Conference on Cultural and Language in Southeast Asia (ICCLAS). Jakarta Indonesia.

Baker. M. (2011). In other words: A coursebook on translation. London: Routledge.

Catford. J.C. (1978). A linguistic theorv of translation: An essav in applied linguistics. London: Oxford University Press.

Collin. P.H. \& N Kassis. T Angel. (1990). Harran's English dictionarv for speakers of arabic. Canada: Kernerman Publishing. Inc.

Hallidav. M.A.K. (1994). An introduction to functional grammar. Second edition. London: Edward Arnold.

Miles. M B. \& Huberman. A.M. (1994). An exnanded sourcehook qualitative data analysis. London: Sage Publications.

As-Samaraandiv. Abil-Laist Nashr. Tanbīhul-ghāfilīn. Kairo: Maktabatul-İ̀man bil-Manshūrah.

Sukesti. R. (2011). Tema - rema dalam bahasa Jawa ngoko dialek Banvumas: kaiian penataan organisasi informasi. .Jurnal Humaniora. 23(2). 219-228.

Suparno. (1993). Konstruksi tema rema dalam hahasa Indonesia lisan tidak resmi masvarakat Kotamadva Malang. Jakarta: Pusat Pembinaan dan Pengembangan Bahasa.

Vachek. J. (2003). Dictionarv of the nraque school of lineuistics. Amsterdam: John Benjamins Publishing Companv.

Zainul-Musthafa. Mishbach Ibnu. (1985). Tariamah tanhīhulghäfilìn: juz 1. Semarang: Al-Maktabah Al-Alawiyyah. 